\title{
Optimization and immobilization of amylase produced by Aspergillus terreus using pomegranate peel waste
}

\author{
Nehad E. Ahmed, Aliaa R. El Shamy and Hassan M. Awad*i(D)
}

\begin{abstract}
Background: Amylases are amongst the most important hydrolytic enzymes that are used in numerous industrial uses reaching for food to pharmaceuticals. Immobilization of enzymes can proposal several assistances as reusability and retrieval from their products improve strength under both operating and storing environments.

Results: Marine fungal isolate was recovered from red sea water at Sharm El-Sheikh Province and was tested for amylase activity using different agricultural wastes as substrate. It was found that pomegranate peel was the best substrate for amylase production $(339 \mathrm{U} / \mathrm{ml})$. Thus, it was subjected for identifying by $185 \mathrm{rDNA}$ gene. The phylogenetic analysis results indicated that this fungal isolate belonged to Aspergillus species with similarity of $99 \%$ and named as Aspergillus terrus SS_RS-NE. Its nucleotide sequences were deposited in NCBI GenBank under accession no. of MN901491. Some parameters affecting amylase activity using pomegranate peel as substrate were studied. The results denoted that, the highest amylase activity of $340.69 \mathrm{U} / \mathrm{ml}$ using $1.5 \%$ pomegranate peel at 30 ${ }^{\circ} \mathrm{C}$, pH 6.0 on 5 days incubation time by Aspergillus terreus. The produced crude enzyme was partially purified with $80 \%$ ammonium sulfate followed by dialysis. The enzyme activity was $1246 \mathrm{U} / \mathrm{ml}$ and $2411 \mathrm{U} / \mathrm{ml}$ employing ammonium sulfate precipitation and dialysis respectively.

The partially purified amylase was immobilized with $2 \%$ sodium alginate and the results showed the highest immobilized enzyme yield was $92.8 \%$. The characterizations of immobilized amylase were studied and the results indicated that, the maximal immobilized amylase activity was $2522.5 \mathrm{U} / \mathrm{ml}$ with $2 \%$ starch as a substrate at optimum pH value of 6.5 , temperature at $60^{\circ} \mathrm{C}$ and 10 min reaction time in comparison to maximal free amylase enzyme at $\mathrm{pH} 5,50^{\circ} \mathrm{C}$ after $40 \mathrm{~min}$. The results also indicated the immobilized amylase was stable at $60{ }^{\circ} \mathrm{C}$ for 20 min.

Conclusions: Aspergillus terrus SS_RS-NE (MN901491) was isolated and genetically identified. It has the ability to produce amylase enzyme using pomegranate peel waste with a yield of $339 \mathrm{U} / \mathrm{ml}$. The crude enzyme was partially purified by ammonium sulfate followed by dialysis. The maximal immobilized amylase activity of $2522.5 \mathrm{U} / \mathrm{ml}$ was obtained under optimized some culture conditions and medium nutrient parameters.
\end{abstract}

Keywords: Marine fungal isolation and genotypic identification, Amylase production, Immobilized amylase, Pomegranate peel waste, Optimization production, Enzyme characterization and purification

\footnotetext{
* Correspondence: awadmhassan@yahoo.com

Chemistry of Natural and Microbial Products Department, Pharmaceutical

and Drug Industries Research Division, National Research Centre, Cairo, Egypt
}

\section{Springer Open}

(- The Author(s). 2020 Open Access This article is licensed under a Creative Commons Attribution 4.0 International License, which permits use, sharing, adaptation, distribution and reproduction in any medium or format, as long as you give appropriate credit to the original author(s) and the source, provide a link to the Creative Commons licence, and indicate if changes were made. The images or other third party material in this article are included in the article's Creative Commons licence, unless indicated otherwise in a credit line to the material. If material is not included in the article's Creative Commons licence and your intended use is not permitted by statutory regulation or exceeds the permitted use, you will need to obtain permission directly from the copyright holder. To view a copy of this licence, visit http://creativecommons.org/licenses/by/4.0/. 


\section{Background}

Amylases are the most important enzymes which hydrolyze starch molecules to dextrin and smaller polymers composed of glucose unit (Gupta et al. 2009). Amylases are a cluster of hydrolases that can definitely cleave the $\alpha$-glycosidic bond in starch. Amyalses are classified as three important groups according to their action and properties to $\alpha$-amylase, $\beta$-amylase, and glucoamylase. -amylases (endo-1,4- -D-glucan glucohydrolase, EC 3.2.1.1) are extracellular enzymes that catalyze hydrolysis of 1,4- $\alpha$-D-glucosidic bonds in the internal of the starch molecule in a random way, creating branched and linear oligosaccharides (dextrin, maltose, maltotriose, glucose) of diverse chain length (Khan and Priya 2011). -amylases (1,4- $\beta$-D-glucan maltohydrolase, EC 3.2.1.2) are typically of plant source, but a rare microbial strains are similarly recognized to yield them. It is an exacting enzyme that splits non reducing ends of amylose, amylopectin, and glycogen molecule. Glucoamylase (Exo-1,4- -D-glucan glucanohydrolase, EC 3.1.2.3) hydrolysis sole glucose units from the nonreducing ends of amylose and amylopectin, these enzymes are the most important enzymes in biotechnology which constitute a class of industrial enzymes, approximately $25 \%$ of the world enzyme market. Amylases are the second largest group of enzymes used all over the world. They are widely used in biotechnology industries in starch saccharification processes, such as in textile industries, food and animal feed, detergents, fermented beverages and distilleries. In addition, they also have potential application in pharmaceutical, refined chemical, and bakery industries (Gurung et al. 2013). They can also be applied in recycling and paper production as well as in the juice industry, where they are used to clarify and decrease turbidity (Pandey et al. 2005).

Amylases are broadly dispersed in the environment and can be obtained from various springs, such as plants, animals, and microorganisms, but the main benefit of using microorganisms for the amylases production is the reasonable bulk production capability, also easily manipulated to obtain enzymes of desired characteristics (Karnwal and Nigam 2013). Amylase can be obtained from several fungi, yeast, bacteria and actinomycetes (ElShahed et al. 2008). The fungal amylases are preferred over other microbial sources because of the accessibility and extraordinary efficiency of fungi, which are similarly agreeable to genomic guidance. Many fungi had been found to be good sources of amylolytic enzymes.

Amylase production has been reported in several different fungi species such as Fusarium solani (Kumar et al. 2012), Aspergillus oryzae (Ichinose et al. 2014), Aspergillus niger (Varalakshmi et al. 2009) and Streptomyces erumpens (Kar et al. 2008). Rizk et al. (2019) studied the production of $\alpha$-amylase by Aspergillus niger, they showed that activity of $\alpha$-amylase increased by increasing $\mathrm{pH}$ value up to $\mathrm{pH}$ 6.5. The maximum activity of $\alpha$ amylase was recorded at temperature $45{ }^{\circ} \mathrm{C}$. Rizk et al. (2019) mentioned that $\alpha$-amylase activity from Aspergillus niger increased by increasing $\mathrm{pH}$ value up to $\mathrm{pH} 6.5$. The maximum $\alpha$-amylase activity was obtained at $45{ }^{\circ} \mathrm{C}$. Also, Jain and Katyal (2018) optimized some production conditions of amylases from Aspergillus sp. and they indicated that the maximal amylase activity of $126.34 \mathrm{U} /$ $\mathrm{ml}$ and $243.09 \mathrm{U} / \mathrm{ml} 243.09 \mathrm{U} / \mathrm{ml}$ by $A$. terreus and $A$. niger, respectively.

Agro industrial remains are usually careful as the best substrate for the effective cost cutting in the production of alpha amylases. The choice of a substrate (agrarian waste) for enzyme production relies on a few factors for the most part correlated with the charge and accessibility of the substrate, the solid substrate not just deliveries the nutrients to the microbial culture developing in it yet additionally fills in as a harbor for the cells (Nimkar et al. 2010). These agriculture wastelands comprise of Cand $\mathrm{N}$-sources required for the growing and breakdown of microorganisms (Djekrif-Dakhmouche et al. 2006; Haq et al. 2005).

The utilization of enzymes in a free structure is uneconomic in light of the fact that the enzymes for the most part cannot be re-extracted at the end of the process; immobilized enzyme procedure forestalls enzyme misfortunes and simultaneously keeps up enzymes at extraordinary concentrations so as to diminish the expense of the enzymes (Baldino et al. 2001).

Overall, an immobilized form of amylase has exposed greater stability in comparing with free enzymes. It presented the reprocess of this biocatalyst for repetitive fermentation method and furthermore can be effortlessly isolated from the reaction mix (Konsoula and Liakopoulou-Kyriakides 2006). Among different immobilization strategies, capture is one of the most ideal strategies since it forestalls over the top loss of protein action, shields chemical from microbial infection (Cabral et al. 1993). Enzyme immobilization by capture creates the molecule structure which permits contact between the substrate and enzyme to be accomplished and, furthermore, it is conceivable to immobilize a numerous catalysts simultaneously (Hari et al. 1996). Physical ensnarement of $\alpha$-amylase in calcium alginate globules has appeared as a generally simple, quick, and safe strategy (Wolfgang Gerhartz 1990). de Souza et al. (2019) immobilized crude fungal amylase extracts from Aspergillus ATCC 3940 by diverse preparation techniques of alginate and chitosan. The maximal immobilization productivity achieved was $97.38 \%$ at $\mathrm{pH} 5$ and $45{ }^{\circ} \mathrm{C}$. The immobilized scheme might be enhanced by accumulated amylase concentration in immobilized 
support, which would probable consequence in greater exchange rates of starch into sugars.

The objective of this study was isolation and molecular identification of fungal isolate, screening of different agricultural waste as substrates for maximal amylase production by Aspergillus terreus. Optimization of culture conditions, e.g., incubation time, temperature, and initial $\mathrm{pH}$ for amylase production and enzyme partially purified. Finally, enzyme immobilized using sodium alginate and studying its properties.

\section{Materials and methods}

\section{Microorganism}

The marine fungal strain was isolated from red sea water at Sharm El-Shiekh province and identified by $18 \mathrm{~S}$ ribosomal RNA gene. The fungal culture was maintained on potato dextrose agar (PDA), incubated at $30{ }^{\circ} \mathrm{C}$ for 7 days and stored in the refrigerator at $4{ }^{\circ} \mathrm{C}$.

\section{Molecular identification of fungal isolate DNA isolation}

DNA extraction was done by using the protocol of Gene Jet genomic DNA purification kit (Thermo\# K0791) following the manufacturer's instruction.

\section{PCR amplification and sequencing}

The PCR amplification of $18 \mathrm{~S}$ rDNA region was carried out following the manufacture of Maxima Hot Start PCR Master Mix (Mix (Thermo) \#K0221). The 18SrDNA was amplified by polymerase chain reaction (PCR) using primers designed to amplify a $1500 \mathrm{bp}$ fragment of the 18SrDNA region. The ITS1-5.8S-ITS2 genomic region was amplified from genomic DNA using the forward primer ITS1 (5-TCCGTAGGTGAACCTGCGG-3) and the reverse primer ITS4 (5-TCCTCCGCTTATTGATAT GC-3) (White et al. (1990); Hamed et al. (2015).

The PCR reaction was performed with $2 \mu \mathrm{l}$ of $10 \times$ Taq PCR buffer, $1.6 \mu \mathrm{l}$ from $2.5 \mathrm{mM}$ dNTP Mixture, $1 \mu \mathrm{l}$ of both forward and reverse primers $(10 \mathrm{pmol} / \mu \mathrm{l}), 2 \mu \mathrm{l}$ template genomic DNA $(20 \mathrm{ng} / \mu \mathrm{l}), 0.2 \mu \mathrm{l}$ from KOMATaq. $(2.5 \mathrm{U} / \mu \mathrm{l})$ and distilled water (HPLC grade) up to $20 \mu \mathrm{l}$. The reaction mixture as follows: initial denaturation at $95{ }^{\circ} \mathrm{C}$ for $1 \mathrm{~min}, 30$ cycles dent. $95{ }^{\circ} \mathrm{C}$ for $30 \mathrm{~s}$, annealing $55^{\circ} \mathrm{C}$ for $2 \mathrm{~min}$, extension $68{ }^{\circ} \mathrm{C}$ for $1.5 \mathrm{~min}$, final extension $68{ }^{\circ} \mathrm{C}$ for $10 \mathrm{~min}$ for 1 cycle. After completion, the PCR products were electrophoresed on $1 \%$ agarose gels, containing ethidium bromide $(10 \mathrm{mg} \mathrm{ml})$, to ensure that a fragment of the correct size had been amplified.

The amplification products were purified Montage PCR clean up kit (Millipore). The purified PCR products were sequenced by using the 2 primers that used before in the PCR reaction. Sequencing was performed by big dye terminator cycle Sequencing kit V.3.1 (Applied
Biosysytems, USA). PCR products were resolved on an Applied Biosysytems Model 3730XL Automated DNA sequencing system (Applied Biosysytems, USA) at the Macrogen, INC, Seoul South Korea.

\section{Phylogenetic analysis and tree construction}

Phylogenetic data were obtained by aligning the nucleotides of different $18 \mathrm{~S}$ rRNA retrieved from a BLAST algorithm (www.ncbi.nlm.nih.gov/BLAST), using the CLUSTAL W program version 1.8 with standard parameters. Phylogenetic and molecular evolutionary analyses were conducted using Mega 6 program (Tamura et al. 2013). All analyses were performed on a bootstrapped data set containing 100 replicates (generated by the program). The GC mol \% was generated from NEBcutter, version 1.0 , is a program available via a web server (http://tools.neb.com/NEBcutter).

\section{Substrates}

Different agricultural wastes (wheat bran, rice straw, soy bean, pomegranate peel, banana peel, orange peel, and potato peel) were used as a carbon source for the production of amylase. The proximate chemical composition for each substrate is presented in Table 1.

All wastes were obtained locally, washed, dried at 70 ${ }^{\circ} \mathrm{C}$ in an oven and milled using blender before use. One substrate further was selected to give the maximum amylase production.

\section{Fermentation medium and enzyme production}

For amylase production, two discs (6 $\mathrm{mm}$ in diameter) from culture were inoculated into $250 \mathrm{ml}$ Erlenmeyer conical flasks containing $50 \mathrm{ml}$ of the production medium (g/l): $\mathrm{KH}_{2} \mathrm{PO}_{4} \quad 1.4 ; \mathrm{NH}_{4} \mathrm{NO}_{3} 10 ; \mathrm{KCl} \quad 0.5$; $\mathrm{MgSO}_{4} .7 \mathrm{H}_{2} \mathrm{O}$ 0.1; $\mathrm{FeSO}_{4} .7 \mathrm{H}_{2} \mathrm{O}$ 0.01; soluble starch 20 . The medium was incubated rotary shaker Innova 4080 (New Brunswick, NJ, USA) at $150 \mathrm{rpm}$ and $30{ }^{\circ} \mathrm{C}$ for 6 days. The medium was centrifuged at $10,000 \mathrm{rpm}$ for 15 min to obtain a crude enzyme.

\section{Enzyme assay}

Enzyme activity was determined by DNS by a method described by Mandels et al. (1976) using starch as the substrate. The reaction mixture contained the following in a total volume of $2 \mathrm{ml}: 1 \mathrm{ml}$ of enzyme extract added $1 \mathrm{ml}$ of $1 \%$ soluble starch in citrate phosphate buffer (pH 6.5) and incubated in a water bath at $40{ }^{\circ} \mathrm{C}$ for 30 min, and the reaction was stopped by adding $1 \mathrm{ml}$ of DNS reagent (3, 5-dinitro salicylic acid, Sigma-Aldrich Spruce Street, St. Louis, USA) and boiled for $5 \mathrm{~min}$ at 80 ${ }^{\circ} \mathrm{C}$. After stopping the reaction, the tubes were cooled and the absorbance was read at $540 \mathrm{~nm}$. The amount of glucose produced was calculated by referring to the standard plot using glucose as the reducing sugar. 
Table 1 The proximate chemical composition for different agricultural wastes used as a substrate

\begin{tabular}{|c|c|c|}
\hline $\begin{array}{l}\text { Different agricultural } \\
\text { wastes }\end{array}$ & Proximate chemical composition & Reference \\
\hline Wheat bran & $\begin{array}{l}\text { Moisture } 8.1-12.7 \% \text {, protein } 9.6-18.6 \% \text {, Ash 3.9-8.1\%, dietary fiber 33.4-63\%, total carbohydrate } 60-75 \% \text {, } \\
\text { and starch } 9.1-38.9 \% \text {. }\end{array}$ & (Curti et al. 2013) \\
\hline Rice straw & Lignin 13.3\%, cellulose 31.1\%, hemicelluloses 22.3\%; Asha and other 33.3\% & $\begin{array}{l}\text { (Barmina et al. } \\
\text { 2013) }\end{array}$ \\
\hline Soy bean & $\begin{array}{l}\text { Sugar } 6 \% \text {, oil } 20 \% \text {, crude protein } 37 \% \text {, soluble fiber } 12 \% \text {, humidity } 9 \% \text {, ashes } 5 \% \text {, and neutral detergent } \\
\text { fiber } 11 \%\end{array}$ & $\begin{array}{l}\text { (Karr-Lilienthal } \\
\text { et al. 2006) }\end{array}$ \\
\hline $\begin{array}{l}\text { Fresh pomegranate } \\
\text { peel powder }\end{array}$ & $\begin{array}{l}\text { Moisture } 7.27 \% \text {, protein } 3.76 \% \text {, ash } 4.32 \% \text {, crude fiber } 17.31 \% \text {, fat } 0.85 \% \text {, total phenol content } 18.75 \mathrm{mg} / \\
\text { g, antioxidant activity } 59.64 \% \text {, water activity } 0.28 \text {, and carbohydrate } 66.51 \% \text {. }\end{array}$ & $\begin{array}{l}\text { (Ranjitha et al. } \\
\text { 2018) }\end{array}$ \\
\hline $\begin{array}{l}\text { Fresh banana peel } \\
\text { powder }\end{array}$ & $\begin{array}{l}\text { Proteins } 0.9 \% \text {, lipids } 1.7 \% \text {, carbohydrates } 59.1 \% \text { crude fiber } 31.7 \% \text {, water } 6 \text { and } 8 \% \text {, minerals: potassium } \\
0.078 \% \text {, manganese } 0.076 \% \text {, calcium } 0.019 \% \text {, sodium is } 0.024 \% \text {, and iron } 0.00061 \% \text {. }\end{array}$ & $\begin{array}{l}\text { (Anhwange et al. } \\
\text { 2009) }\end{array}$ \\
\hline $\begin{array}{l}\text { Fresh orange peel } \\
\text { powder }\end{array}$ & $\begin{array}{l}\text { Ash } 4.2 \% \text {, protein } 7.8 \% \text {, starch } 4.5 \% \text {, fat } 2.3 \% \text { : lignin } 1.0 \% \text {, cellulose } 11.1 \% \text {, and hemicelluloses } 12.6 \% \text {, } \\
\text { pectin } 51.1 \% \text {, and moisture } 2.9 \% \text {. }\end{array}$ & (Hiri et al. 2015) \\
\hline Potato peel powder & Moisture $11.2 \%$, ash $7.56 \%$, sugar $3.45 \%$, carbohydrate $64.47 \%$, and protein $13.52 \%$. & $\begin{array}{l}\text { Arapoglou et al. } \\
\text { 2010) }\end{array}$ \\
\hline
\end{tabular}

One unit of amylase activity was defined as the amount of enzyme that releases $1 \mu \mathrm{mol}$ of glucose per minute under the assay conditions.

\section{Optimization of culture conditions for amylase production}

Effect of agricultural waste on amylase enzyme production

The enzyme production was studied by using seven different agriculture wastes, e.g., wheat bran, rice straw, soy bean, pomegranate peel, banana peel, orange peel, and potato peel replacing the natural carbon source in the fermentation medium, cheapest and plentifully materials for the amylase production. All agriculture wastes were screened as fermentation substrates for maximum amylase production. The best waste concentration for maximum amylase activity was investigated using different concentrations ranging from 10 to $50 \mathrm{mg} / \mathrm{ml}$.

\section{Effect of incubation time on amylase production}

To measure the optimum incubation time for fungal strain growth and amylase production, the fungal culture was cultivated in production medium and incubated for different incubation time $3,4,5,7,10$, and 12 days at 30 ${ }^{\circ} \mathrm{C}$ on an incubator shaker at $150 \mathrm{rpm}$.

\section{Effect of temperature on amylase production}

In order to determine the optimum temperature for amylase production by the fungal strain fermentation was carried out at different temperatures by $25,28,30$, 32 , and $35^{\circ} \mathrm{C}$.

\section{Effect of $\mathrm{pH}$ on amylase production}

The effect of the $\mathrm{pH}$ value was investigated by cultivation the fungal strain in production medium. Media were adjusted to different $\mathrm{pH}$ values $3.5,4.0,4.5,5.0,5.5$, $6.0,6.5$, and 7.0 with $\mathrm{NaOH}(0.1 \mathrm{~N})$ or $\mathrm{HCl}(0.1 \mathrm{~N})$.

\section{Partial purification of the enzyme}

Alpha amylase was partially purified by ammonium sulfate fractionation followed by dialysis. The crude enzyme was purified by ammonium sulfate precipitation to $80 \%$ saturation in an ice bath. The precipitated protein was collected by centrifugation at 10,000 rpm for $10 \mathrm{~min}$ at 4 ${ }^{\circ} \mathrm{C}$ and dissolved in a minimum volume of phosphate buffer $(0.1 \mathrm{M}$; pH 7.0). The enzyme solution was dialyzed at $4{ }^{\circ} \mathrm{C}$ against the same buffer for $24 \mathrm{~h}$ at $4{ }^{\circ} \mathrm{C}$. The dialysis was concentrated through a freeze dryer and dissolved in a minimum volume of phosphate buffer (0.1 M; pH 7.0).

Amylase activity from partially purified samples was assayed by DNS method. Then, the final concentrated enzyme solution was taken for comparative enzyme entrapment study.

\section{Enzyme immobilization Preparation of alginate beads}

Alginate gel beads were prepared according to Awad et al. (2016). Sodium alginate (Alg) was dissolved in distilled water, a volume of enzyme solution and sodium alginate solution was mixed to give a final concentration of $2 \%, 3 \%$, and $4 \%(\mathrm{w} / \mathrm{v})$. The calcium alginate gel beads were formed by dropping the mixture alginate solution from a height of approximate $20 \mathrm{~cm}$ through a nozzle of $300 \mu \mathrm{m}$ using syringe into $100 \mathrm{ml}$ solution containing $3 \% \mathrm{CaCl}_{2}(\mathrm{w} / \mathrm{v})$ by a syringe with continuous stirring. The beads were left in the solution for $24 \mathrm{~h}$. The calcium alginate beads containing the enzyme were thoroughly washed with distilled water and used for further studies.

\section{Immobilized enzyme assay}

Enzyme activity was assayed by the DNS method as mention above in the free enzyme method. 


\section{Determination of enzyme immobilization yield}

The immobilization yield was defined here as the yield for an enzyme which was immobilized in the calcium alginate beads and expressed by the following equation:

Immobilization yield $(\%)=($ activity of immobilized enzyme $/ A-B) \times 100$

Where $A$ is the activity of free enzyme added, and B is the activity of remaining enzyme in washed water and filtered calcium chloride solution (activity of unbound enzyme). Both $A$ and $B$ were evaluated for the amount of reducing sugars produced enzymatically in the corresponding solutions.

Optimization of parameters for enzyme immobilization Different sodium alginate concentrations $(2-4 \% \mathrm{w} / \mathrm{v})$ and calcium chloride concentrations (3\%) were used during immobilization on $\alpha$-amylase to achieve $100 \%$ immobilization yield. Also, various factors were studied to evaluate the activity of both the free and immobilized amylase such as incubation time, temperature, $\mathrm{pH}$, and thermal stability of the enzymes.

\section{Effect of substrate concentration on a-amylase activity} The best of substrate concentrate (soluble starch) of immobilized amylase was determined using different starch concentrations $(0.25-2.5 \%)$.

\section{Effect of incubation time on a-amylase activity}

To measure the optimum incubation time for free and immobilized amylase, the reaction mixture at different incubation time (10-60 $\mathrm{min}$ ) were investigated.

\section{Effect of temperature and $\mathrm{pH}$ on a-amylase activity}

The optimum temperature of free and immobilized amylase was measured by incubating the reaction mixture of both free and immobilized enzymes at different temperatures ranging from 25 to $70{ }^{\circ} \mathrm{C}$. The effect of $\mathrm{pH}$ on enzyme activity was determined by incubation of free and immobilized amylase at optimum temperatures in the $\mathrm{pH}$ range of 4-7 using citrate phosphate buffer $(\mathrm{pH}$ $4-7)$.

\section{Effect of thermal stability of the enzyme}

Enzyme thermal stability of the immobilized enzyme was determined at high temperatures, the enzyme was incubated in the enzyme's buffer solution at different temperatures $\left(25,30,40,50,60^{\circ} \mathrm{C}\right)$ for different incubation periods (10-60 $\mathrm{min})$, and then they were examined for enzyme activity as mentioned above.

\section{Results}

Molecular identification of the isolate DNA extraction and PCR amplification

The DNA content of SS_RS-NE strain was exposed to PCR via general primers to intensify the ITS1 and ITS4 regions among the minor and great nuclear rDNA, counting the $18 \mathrm{~S}$ rDNA. The DNA fragment of $490 \mathrm{bp}$ was improved by these primers.

The nucleotide sequence (490 bp) of strain Aspergillus terrus SS_RS-NE was blasting the sequence with the obtainable GenBank sources by NCBI-BLAST (www.ncbi. nlm.nih.gov/BLAST) to associate the SS_RS-NE isolate through those of adherent Aspergillus sp. microorganisms. The outcomes exhibited that the highest sequence correspondence types (99\%) with Aspergillus terrus strains.

\section{Phylogenetic analysis and GC\%}

The phylogenetic tree (Fig. 1) showed that strain SS RS-NE is most nearly correlated to Aspergillus terrus. Consequently, it was suggested a name Aspergillus terrus SS_RS-NE. The GC\% is one of numerous universal structures used to describe fungal genomes. The GC contented of the genomic DNA was 59 mol\% for SS_RS-NE isolate was achieved from the phylogenetic examination.

\section{GenBank accession number}

The nucleotide sequences of $18 \mathrm{~S}$ rRNA gene of Aspergillus terrus SS_RS-NE have been placed in GenBank under accession number MN901491.

\section{Effect of different agricultural wastes on amylase production by Aspergillus terreus}

Various agricultural wastes such as wheat bran, rice straw, soy bean, pomegranate peel, banana peel, orange peel, and potato peel were used as cheap and most economical carbon source for amylase production by Aspergillus terreus. The results in Fig. 2 showed that the maximal amylase activity was noticed using pomegranate peel $(339 \mathrm{U} / \mathrm{ml})$ as the substrate, soybean $(273.59 \mathrm{U} / \mathrm{ml})$, followed by banana peel $(232.35 \mathrm{U} / \mathrm{ml})$. While other wastes, e.g., wheat bran, orange peel, potato peel has moderate to low activity. On the other hand, the minimum amylase activity was recorded in rice straw (77.53 $\mathrm{U} / \mathrm{ml}$ ). Thus, pomegranate peel waste was carefully chosen for additional experiment on amylase production.

\section{Effect of different pomegranate peel waste concentrations on amylase production}

The effect of different concentrations of pomegranate peels on the $\alpha$-amylase activity by $A$. terreus was studied. The results illustrated in Fig. 3 showed that 


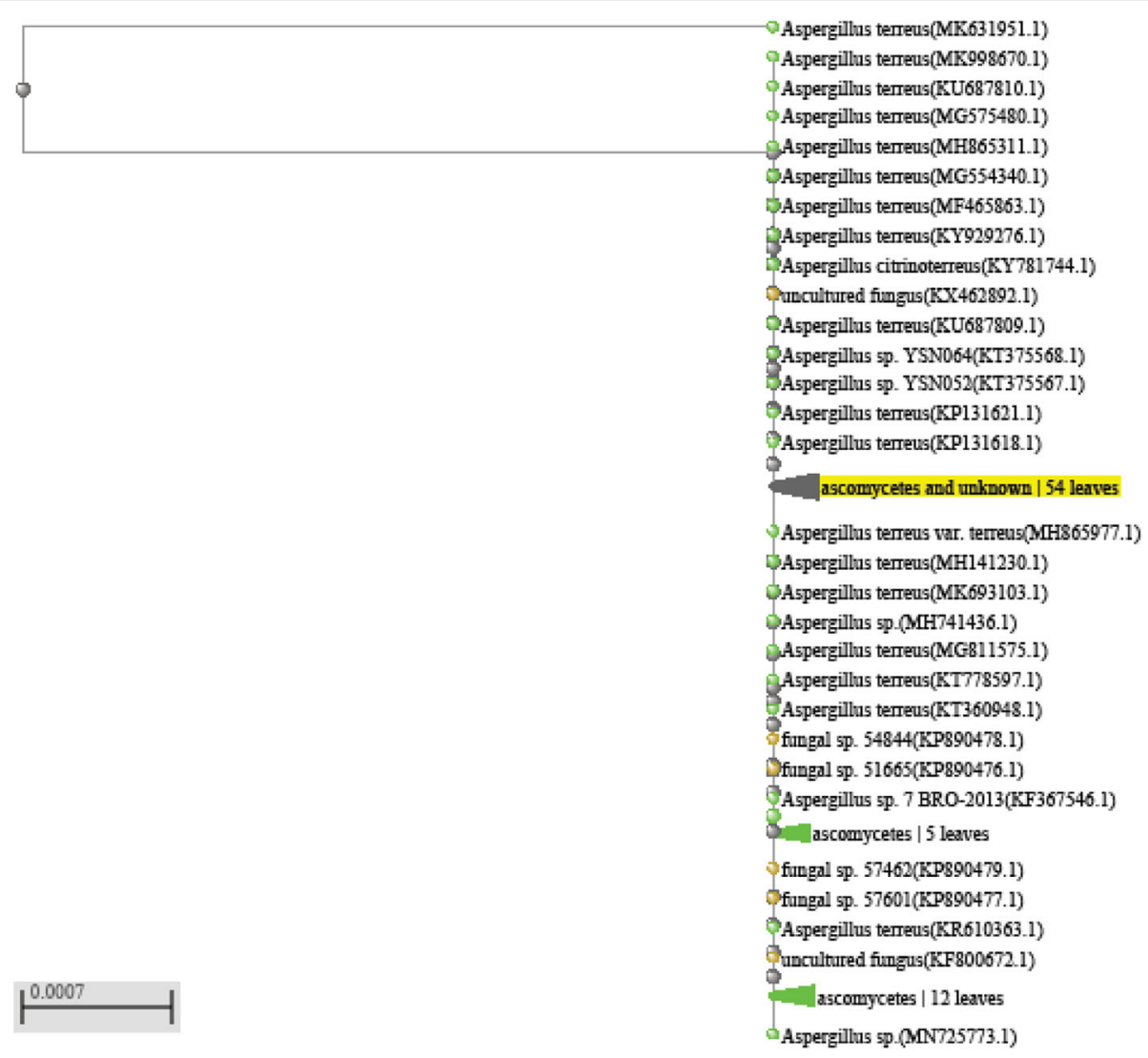

Fig. 1 Phylogenetic tree presenting the relations of Aspergillus terrus SS_RS-NE with other Aspergillus species

A. terreus produced the highest $\alpha$-amylase activity $(340.69 \mathrm{U} / \mathrm{ml})$ at $1.5 \%$ pomegranate peel. Further decrease or increase in the pomegranate peels concentration decreased $\alpha$-amylase production. Most likely, that the substrate concentration influences $\alpha$-amylase creation.

\section{Effect of different incubation time on a-amylase production}

The effect of different incubation time (3-12 days) on amylase production by $A$. terreus using pomegranate peel $1.5 \%$ as carbon source at optimum temperature and $\mathrm{pH}$ were investigated. As shown in Fig. 4a, amylase

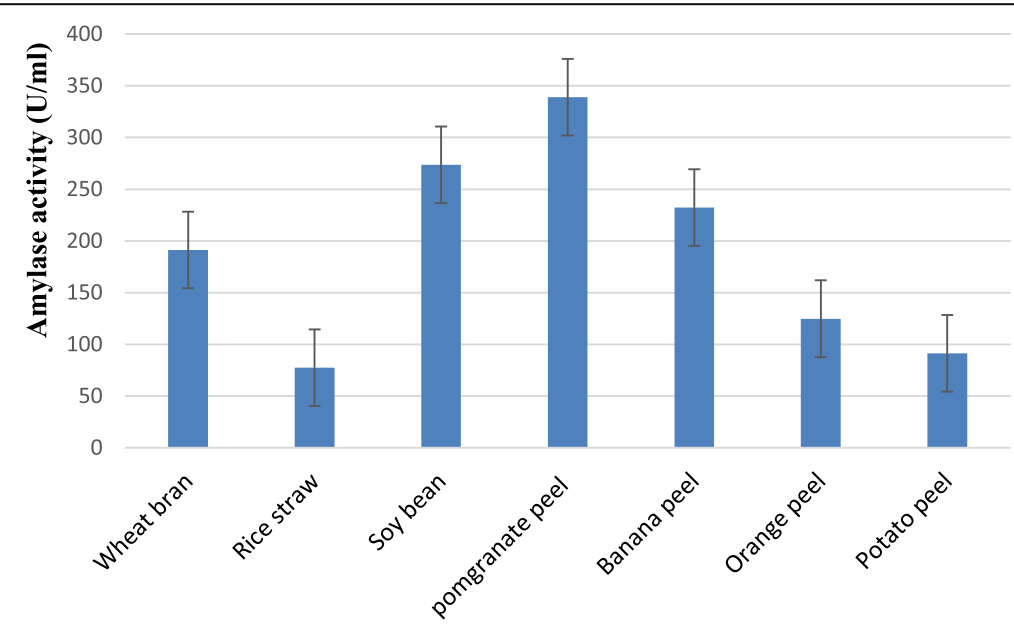

\section{Different wastes}

Fig. 2 Effect of different wastes on a-amylase production by Aspergillus terrus SS_RS-NE 


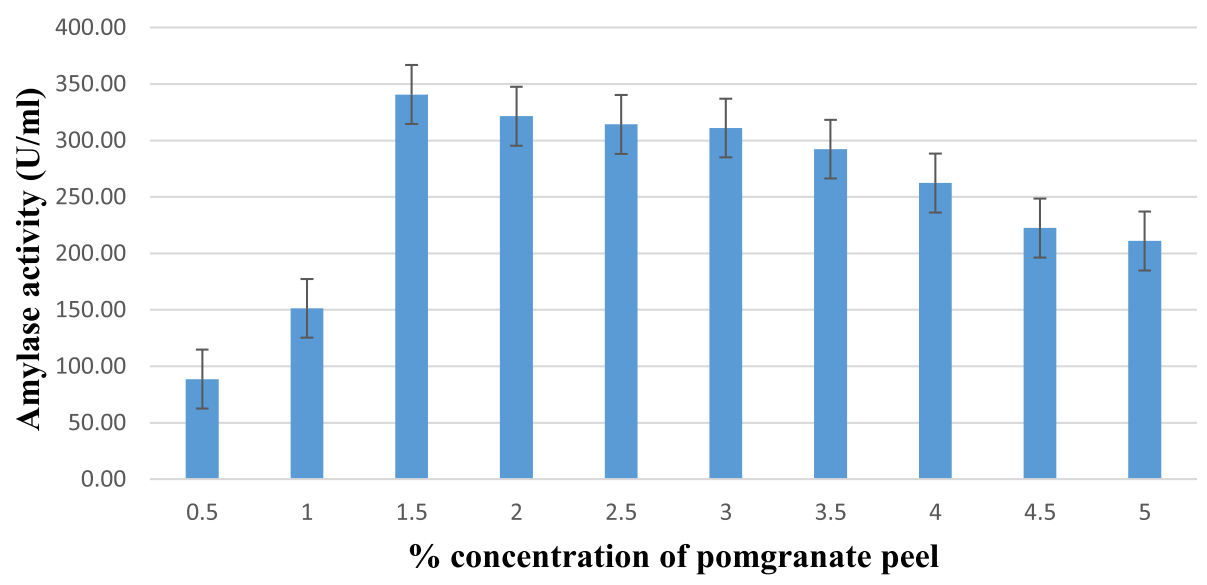

Fig. 3 Effect of different concentration of substrate on a-amylase produced by Aspergillus terrus SS_RS-NE

activity increased gradually with increasing of incubation time till reaching the maximum activity of $343.8 \mathrm{U} / \mathrm{ml}$ on 5 days incubation time, then amylase activity gradually decreased by increasing the incubation time. This may be due to the depletion of essential nutrients required for the growth and enzyme production.

\section{Effect of different $\mathrm{pH}$ values on $\mathrm{a}$-amylase production}

The effect of different $\mathrm{pH}$ of the medium (3.5-7) on the amylases production by $A$. terreus using pomegranate peel $1.5 \%$ was studied. The results in Fig. $4 \mathrm{~b}$ indicated that the maximal enzyme activity of $345 \mathrm{U} / \mathrm{ml}$ was obtained at $\mathrm{pH} 6.0$, over this $\mathrm{pH}$ value, the amylase activity gradually decreased.

\section{Effect of different temperature on amylase activity}

The influence of diverse incubation temperature on the amylase production from $A$. terreus using pomegranate peel $1.5 \%$, for selecting the optimum incubation time and $\mathrm{pH}$ value was studied. The results in Fig. 4c showed that the maximal amylase yield of $348.5 \mathrm{U} / \mathrm{ml}$ was observed at $30{ }^{\circ} \mathrm{C}$, below $30{ }^{\circ} \mathrm{C}$, amylase activity was decreased. Vidyalakshmi et al. (2009) denoted that a temperature is one of the significant elements, which powerfully affect $\alpha$ amylase activity by fermentation procedure.

\section{Partial purification of crude amylase}

The crude enzyme that produced from $A$. terreus using pomegranate peel waste $1.5 \%$ was partly refined by $80 \%$ ammonium sulfate and dialysis. The outcomes in Table 2 indicated that the amylase yield of 1246 and $2411 \mathrm{U} / \mathrm{ml}$ was obtained from $80 \%$ ammonium sulfate and dialysis, respectively, in comparison to crude amylase of $349 \mathrm{U} / \mathrm{ml}$.

\section{Amylase immobilization}

Effect of different concentration of sodium alginate on immobilized enzyme yield

The immobilization yield of enzyme is influenced by on $\mathrm{Na}$ alg. concentration. So, $2-4 \% \mathrm{Na}$ alg. was used for

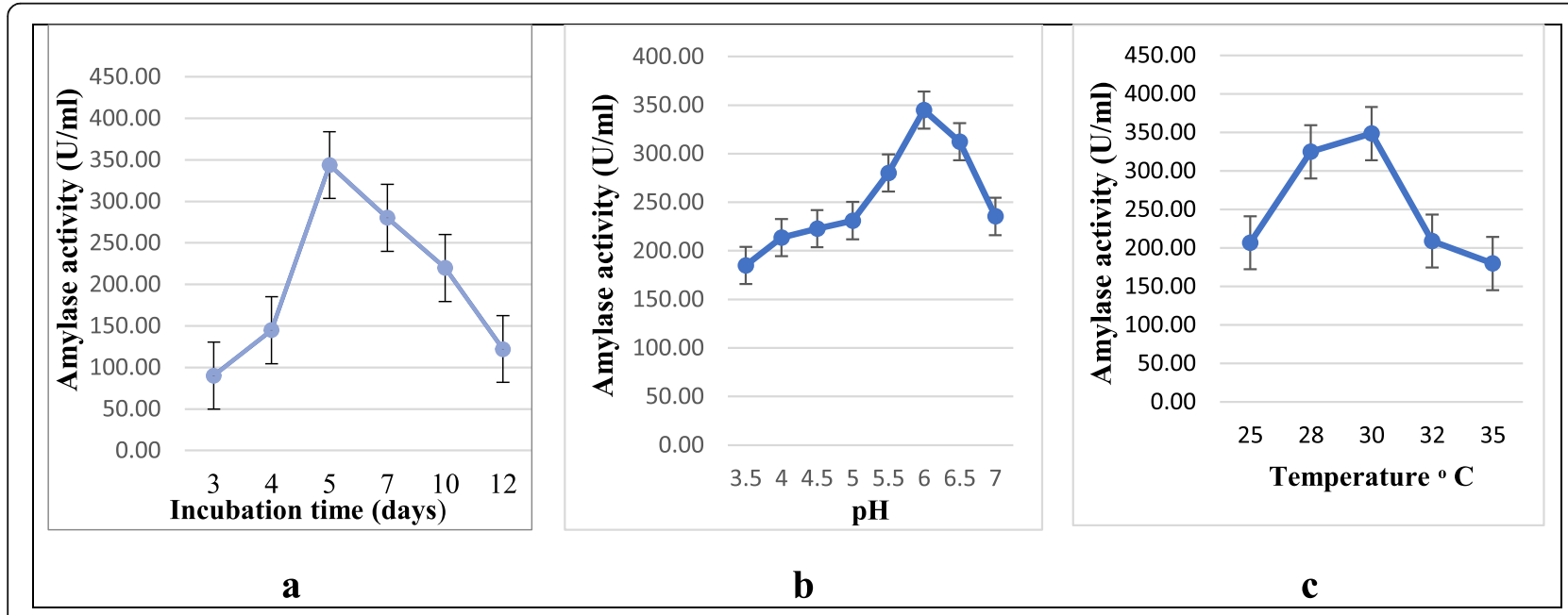

Fig. 4 Effect of different incubation time (a), different pH (b), and different temperature (c) on a-amylase produced by Aspergillus terrus SS_RS-NE 
Table 2 Partial Purification of amylase enzyme produced by Aspergillus terreus

\begin{tabular}{ll}
\hline Steps of partial purification & Amylase activity $(\mathrm{U} / \mathrm{ml})$ \\
\hline Crude enzyme & 349 \\
Precipitate by ammonium sulfate (80\%) & 1246 \\
After dialysis & 2411 \\
\hline
\end{tabular}

immobilized amylase preparation. The results illustrated in Fig. 5 indicated that immobilized amylase with $2 \%$ sodium alginate showed the highest immobilization yield $(92.8 \%)$ while $3 \%$ sodium alginate gave the yield of $86.6 \%$. A lower immobilization yield was obtained by $4 \%$ sodium alginate $(22 \%)$. Immobilization yield decreases with the increasing in the concentration of $\mathrm{Na}$ alg. The pore size of the beads would be such that substrate and product can simply diffuse in and out of the alginate get matrix, but the amylase would retain in the micro environment of beads. Lower concentration of $\mathrm{Na}$ alg solution, the pore size of the beads will be increased and consequently escape of the enzyme from the beads will rise and vies versa (Riaz et al. 2009).

\section{Characterization of amylase immobilized Influence of substrate concentration on immobilized amylase}

The influence of substrate concentration on immobilized amylase activity using different concentrations of starch $(0.25-2.5 \%)$ at $40{ }^{\circ} \mathrm{C}$ for $30 \mathrm{~min}, \mathrm{pH} 6.5$ was studied. The results illustrated in Fig. 6 showed that the activity of immobilized amylase yield gradually increase till reached its maximum activity of $2522.5 \mathrm{U} / \mathrm{ml}$ at $2 \%$ starch, and then the activity was declined.

\section{Effect of different reaction time on the activity of free and immobilized amylase}

The effect of different reaction time (10-60 min) for both free and immobilized amylase was investigated with
$2 \%$ starch. The results in Fig. 7a indicated that the enzyme activity of both free and immobilized amylase was increased with the increasing of enzyme reaction time and substrate. Consequently, the optimum reaction time for free and immobilized amylase was found to be 40 $\mathrm{min}$ and $10 \mathrm{~min}$ of the reaction, over this reaction time, both free and immobilized amylase activity was decreased.

\section{Effect of different $\mathrm{pH}$ values on the activity of free and immobilized amylase}

The $\mathrm{pH}$ is one of the major parameters capable of shifting enzyme activities in the reaction mixture. Immobilization usually results in a shift of optimum $\mathrm{pH}$ due to conformational changes in enzymes. The activity of both free and immobilized amylase was investigated at different $\mathrm{pH}(4-7)$ with $2 \%$ starch. Increasing in $\mathrm{pH}$ has marked effect on free and immobilized amylase enzyme as shown in Fig. $7 \mathrm{~b}$. The results indicated that the optimum $\mathrm{pH}$ for free and immobilized amylase enzyme was 5 and 6.5 , respectively.

\section{Effect of different temperature on free and immobilized amylase}

The activity of free and immobilized amylase was investigated at different temperatures $\left(25-70^{\circ} \mathrm{C}\right)$. The results presented in Fig. 7c showed that, the activity of free and immobilized amylase increase with the increasing the temperature till reached its maximal yield at the optimum temperature of $50^{\circ} \mathrm{C}$ and $60^{\circ} \mathrm{C}$ for free and immobilized enzyme, respectively.

\section{Thermal stability of immobilized amylase}

The thermal stability of the immobilized amylase was studied by incubating the enzyme at different temperature ranging from 25 to $60{ }^{\circ} \mathrm{C}$ and the residual activity was measured according to the standard assay procedure at different incubation time of 10-60 min. As

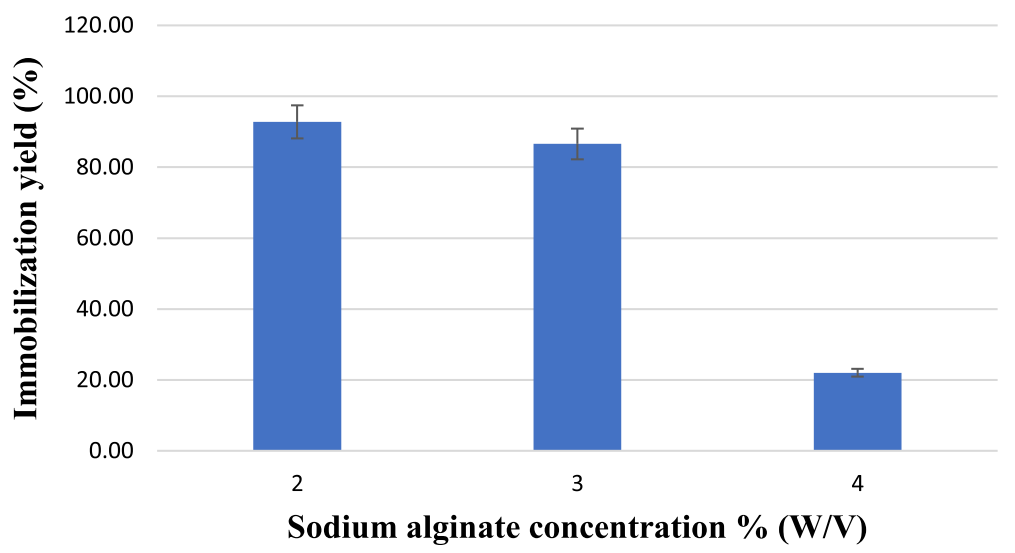

Fig. 5 Effect of concentration of sodium alginate on amylase immobilization yield 


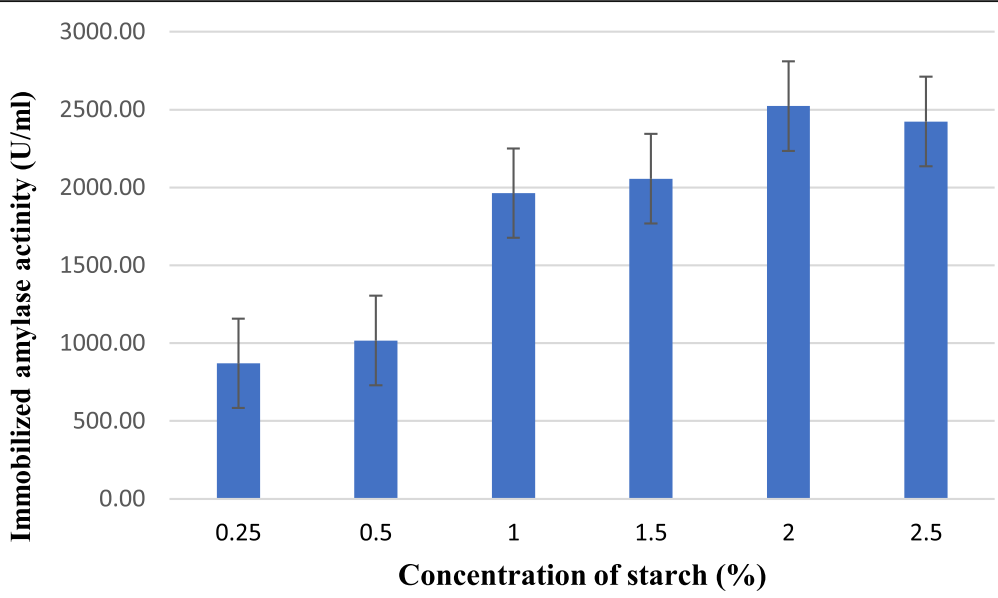

Fig. 6 Effect of concentration of substrate on the activity of immobilized amylase

shown in Fig. 8 the immobilized amylase was stable at $60^{\circ} \mathrm{C}$ for $20 \mathrm{~min}$.

\section{Discussion}

Molecular identification of the isolate was achieved by specific primers that improved a DNA piece of about 490 bp. These outcomes were in covenant with Rasul et al. (2007) who established that these primers are precise for molds and improved a DNA fragment of about 579 bp with some fungi. The GC contented of the genomic DNA was $59 \mathrm{~mol} \%$ for SS_RS-NE isolate. These outcomes were in agreement with Nakase and Komagata (1971) who stated the GC contented of mold varieties from 31.5 to $63 \%$. This variety differed for each class. The compositional variety likewise decays from classes and subclasses to types and sort.

The production of amylase enzyme from fungi using agricultural waste has been investigated by several authors. The maximal amylase activity of 339 $\mathrm{U} / \mathrm{ml}$ was obtained using pomegranate peel as shown in Fig. 2. These results were in covenant with Singh et al. (2014) who found that the maximal amylase of $335.4 \mathrm{U} / \mathrm{ml}$ from Aspergillus fumigatus NTCC1222 using pomegranate peel. On the other hand, these results were greater than the amylase yield of $259 \mathrm{U} /$ $\mathrm{ml}$ and $112 \mathrm{U} / \mathrm{ml}$ that obtained by $A$. niger and $\mathrm{Ba}$ cillus amyloliquefaciens using banana waste wheat bran, respectively (Cyprian et al. 2017; Mojumdar and Deka 2019).

The highest $\alpha$-amylase yield of $340.69 \mathrm{U} / \mathrm{ml}$ at $1.5 \%$ pomegranate peel as noticed in Fig. 3. Similar findings were recorded by Saleh et al. (2011) and Ali et al. (2017) who indicated that the uppermost amylase yield was acquired at $5 \%$ and $3 \%$ of mandarin peel by Trichoderma harzianum and Aspergillus flavus AUMC 11685, respectively.

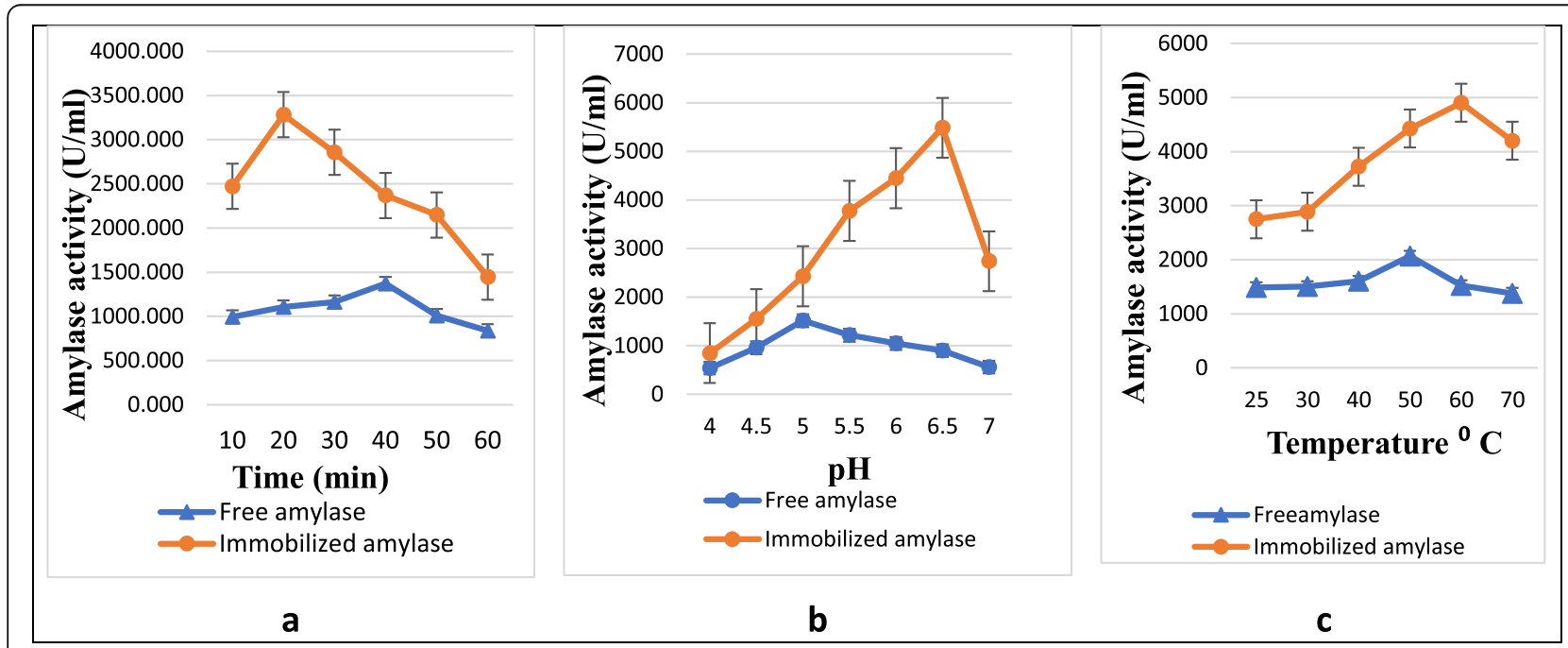

Fig. 7 Effect of different reaction time (a) different pH (b), and different temperature (c) on the activity of free and immobilized amylase 


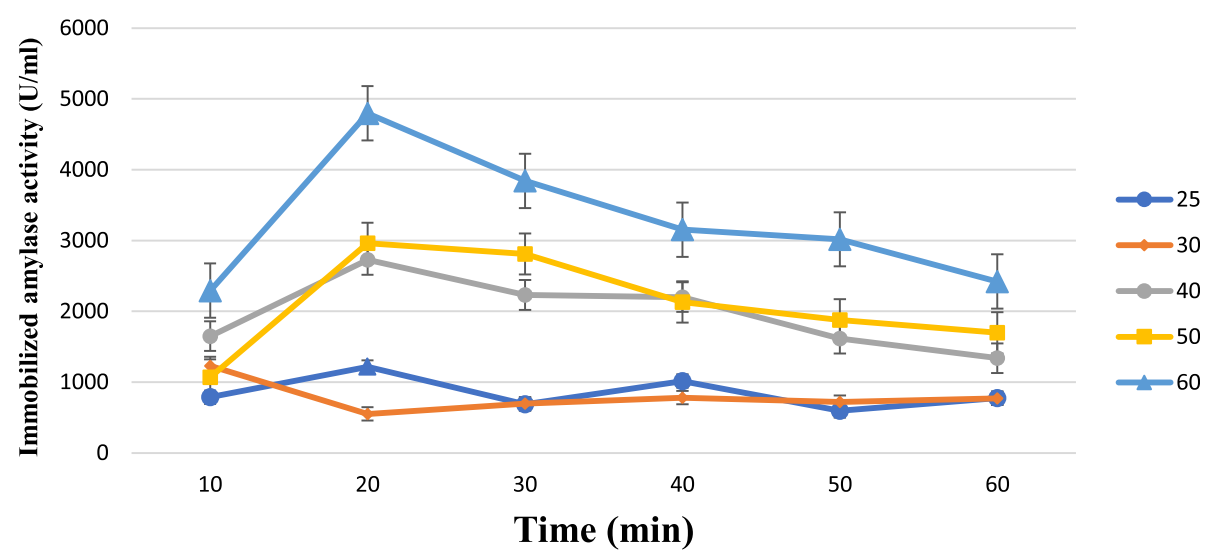

Fig. 8 Thermal stability of immobilized amylase by Aspergillus terrus SS_RS-NE

The effect of different incubation time on the enzyme activity was investigated. The fungal strain produced the maximum amylase activity of $343.8 \mathrm{U} / \mathrm{ml}$ on 5 days incubation time (Fig. 4a). Comparable consequences were informed by Singh et al. (2014) who denoted that the enzyme activity of $262.3 \mathrm{U} / \mathrm{ml}$ by $A$. fumigatus NTCC1222 increase with the increasing in the cultivation period, accomplishment the maximal on the 6th day, the enzyme activity was declined on the 7th and 8th day of incubation period. Also, Ali et al. (2017) found that the highest $\alpha$-amylase yield of $33.52 \mathrm{U} / \mathrm{ml}$ by $A$. flavus AUMC 11685 using mandarin peel was obtained on the 4th day.

Among, the $\mathrm{pH}$ of medium assumes a significant role in inciting morphological variations in molds and in the enzyme excretion (Acourene et al. 2013). The maximal enzyme activity of $345 \mathrm{U} / \mathrm{ml}$ was obtained at $\mathrm{pH} 6.0$ (Fig. 4b). In contrast to our outcomes, Singh et al. (2014) who stated the maximum amylase production by A. fumigatus NTCC1222 was $339.1 \mathrm{U} / \mathrm{ml}$ at an initial $\mathrm{pH}$ 6.0. These results can be compared with those informed by Oyeleke et al. (2010); Pasin et al. (2014) and Ali et al. (2017) they observed that the best initial $\mathrm{pH}$ for amylase production ranged from 5 to 5.5 by $A$. niger, A. japonicus and A. flavus AUMC 11685, respectively.

Temperature is one of the significant elements, which emphatically influence $\alpha$-amylase formation by maturation method (Vidyalakshmi et al. 2009).The optimum temperature that gave the maximal amylase yield of $348.5 \mathrm{U} / \mathrm{ml}$ was observed at $30{ }^{\circ} \mathrm{C}$ (Fig. 4c). These results were in accordance with several authors who observed that amylase activity was optimal at $30{ }^{\circ} \mathrm{C}$ by $A$. oryzae, Penicillium fellutanum, Aspergillus sp. JGI 12 (Ramachandran et al. 2004; Kathiresan and Manivannan 2006; Alva et al. 2007).

The amylase activity was 3.5- and 7-folds were obtained from $80 \%$ ammonium sulfate and dialysis, respectively (Table 1 ). The same consequences were stated by Singh et al. (2014) who found that the specific activity of the partially purified enzyme by ammonium sulfate precipitation and dialysis was 7- and 20-fold purification, individually. As well as, Devi et al. (2012) and Sidkey et al. (2011) reported that $50 \%$ and $60 \%$ ammonium sulfate gave the highest enzyme activity.

The highest immobilized enzyme yield of 92.8\% achieved with $2 \%$ sodium alginate (Fig. 5). The consequences of this work were in concurrence with Mahajan et al. (2010) who indicated that immobilization proficiency and dispersal of substrate into the beads were approved by $1 \%$ sodium alginate. Different concentrations (1.5-5.0\%) of sodium alginate were utilized for the preparation of immobilized enzyme. The amylase was successfully immobilized by entrapping in alginate. These results improve the finding that told the increasing of the concentration of sodium alginate prevents the entrance of substrate into the beads that directed to the lower immobilization efficacy (Dey et al. 2003; Riaz et al. 2009).

The maximum immobilized amylase yield of $2522.5 \mathrm{U} /$ $\mathrm{ml}$ was enhanced at $2 \%$ starch (Fig. 6). Our results were agreed with Hemanchi and Sanjay. (2019) who found that $1 \%$ starch gave the highest immobilized enzyme activity of $2736 \mathrm{U} / \mathrm{ml}$. Also, Zusfahair et al. (2017) indicated that the optimum substrate concentration of immobilized amylase was at concentrations of $1.5-2.5 \%$. This improved necessity of the substrate upon immobilization has been described by Riaz et al. (2007) who found that dissemination of high molecular weight polysaccharide as starch huge will be constrained with the matrix; its diffusional opposition from the bulk solution to the micro environs of an immobilized enzyme can confine the reaction rate.

The enzyme activity of both free and immobilized amylase was increased with the increasing of enzyme reaction time and substrate (Fig. 7a). The obtained results were in accordance with Devi et al. (2012) and Riaz et al. (2015) they mentioned that the maximal immobilized $\alpha$ - 
amylase activity was recorded at $10 \mathrm{~min}$. Beyond $10 \mathrm{~min}$, immobilized $\alpha$-amylase activity was decreased.

Increasing in $\mathrm{pH}$ has marked effect on free and immobilized amylase enzyme. The optimal $\mathrm{pH}$ of 5 and 6.5 was noticed for free and immobilized amylase enzyme (Fig. 7b). These results were most close to the data obtained by Hemanchi and Sanjay. (2019) who mentioned that $\mathrm{pH}$ values of 5.8 and 6.8 were optima for free and immobilized $\alpha$-amylase. On the other hand, our results were in disagreement with Talekar and Chavare (2012) who indicated that the optimal $\mathrm{pH}$ values for free and immobilized amylase was 7 and 5.5, respectively. The change in the optimum $\mathrm{pH}$ of immobilized $\alpha$-amylase due to conformational changes in enzymes; variation in acid and base amino acid side chain ionization in the microenvironment round the active site (Talekar et al. 2010; Prakash and Jaiswal 2011).

The maximal yield for free and immobilized amylase was obtained at $50{ }^{\circ} \mathrm{C}$ and $60{ }^{\circ} \mathrm{C}$ (Fig. 7c). These results were in agreement with Talekar and Chavare (2012); Devi et al. (2012), and Hemanchi and Sanjay (2019) who found that the maximum activity of free and immobilized $\alpha$-amylase was ranged from $50{ }^{\circ} \mathrm{C}$ to $70{ }^{\circ} \mathrm{C}$ using calcium alginate beads.

The immobilized amylase was stable at $60{ }^{\circ} \mathrm{C}$ for 20 min (Fig. 8). Similar results were recorded by El-Banna et al. (2007) who found that free and immobilized $\alpha$ amylase has thermal stability at $60{ }^{\circ} \mathrm{C}$ for $10 \mathrm{~min}$ and were in coincidence with Hemanchi and Sanjay (2019) who mentioned that $40 \%$ relative immobilized $\alpha$-amylase activity was obtained by exposing the beads to $60{ }^{\circ} \mathrm{C}$ for $60 \mathrm{~min}$. The concentration of $50 \%$ of the free enzyme reserved its thermal stability up to $50{ }^{\circ} \mathrm{C}$ compared to $60{ }^{\circ} \mathrm{C}$ to the immobilized enzyme preparation (Foukia et al. 2016).

\section{Conclusions}

Amylases are amongst the most important hydrolytic enzymes that are used in numerous industrial uses reaching from food to pharmaceuticals. Marine fungal was isolated from red sea water at Sharm El-Sheikh region and genotypic identified as Aspergillus terrus SS_RS-NE (MN901491) and it has the ability to produce amylase using pomegranate peel waste with a yield of $339 \mathrm{U} / \mathrm{ml}$. The crude enzyme was partially purified by ammonium sulfate followed by dialysis. The maximal immobilized amylase activity of $2522.5 \mathrm{U} / \mathrm{ml}$ was obtained under optimized some of culture conditions and medium nutrient parameters.

\section{Abbreviations}

PDA: Potato dextrose agar; PCR: Polymerase chain reaction; DNS: 3, 5-dinitro salicylic acid; Rpm: Round per minute; Sod Alg: Sodium alginate; bp: Base pair; GC: Guanine and cytosine; Pp: Pomegranate peel

\section{Acknowledgements}

The authors acknowledge National Research Centre especially Chemistry of Natural and Microbial Products Department, Pharmaceutical and Drug Industries Research Division for their supportive and assurance.

Ethical approval and consent to participate Not applicable

\section{Authors' contributions}

NA: selection of microorganism, enzymes assay, optimization conditions, writing these parts. Fabricated the XYZ of graphs for the experiments. AE: enzyme immobilization, enzyme assay, writing immobilization part. HM: strain identification, writing identification part, formatting, and revising the manuscript. All authors have read and approved the final article.

\section{Authors' information}

Nehad E. Ahmed, Aliaa R. El Shamy and Hassan M. Awad are from the Chemistry of Natural and Microbial Products Department, Pharmaceutical and Drug Industries Research Division, National Research Centre, Dokki, Giza, Egypt.

\section{Funding}

Not applicable

Availability of data and materials

All information generated or analyzed during this work are incorporated in this manuscript.

\section{Consent for publication}

All authors have read and approved to submit it to the Bulletin of the National Research Centre. There is no conflict of interest of any author in relation to the submission.

\section{Competing interests}

The authors declare that they have no competing interests.

Received: 30 April 2020 Accepted: 12 June 2020

Published online: 02 July 2020

\section{References}

Acourene S, Amourache L, Benchabane A, Djaafri K (2013) Utilization of date wastes as substrate for the production of a-amylase. Int Food Res J 20(3): 1367-1372

Ali EH, El-Nagdy MA, Al-Garni SM, Ahmed MS, Rawaa AM (2017) Enhancement of alpha amylase production by Aspergillus flavus AUMC 11685 on mandarin (Citrus reticulata) peel using submerged fermentation. Eur J Biol Res 7(3):154164

Alva S, Anupama J, Savla J, Chiu YY, Vyshali P, Shruti M, Yogeetha BS, Bhavya D, Purvi J, Ruchi K, Kumudini BS, Varalakshmi KN (2007) Production and characterization of fungal amylase enzyme isolated from Aspergillus sp. JGI 12 in solid state culture. Afr J Biotechnol 6(5):576-581

Anhwange B, Nyialagher TD, Ugye JT (2009) Chemical Composition of Musa sepientum (Banana) Peels. Elec J Environ Agric Food Chem 8(6):437-4442

Arapoglou D, Varzakas TH, Vlyssides A, Israilides C (2010) Ethanol production from potato peel waste (PPW). Waste Manag 30:1898-1902

Awad GEA, Abd El Aty AA, Shehata A, Hassan ME, Elnashar MM (2016) Covalent immobilization of microbial naringinase using novel thermally stable biopolymer for hydrolysis of naringin. 3Biotech 6(1):6-14

Baldino AM, Macias, Cantero D (2001) Immobilization of glucose oxidase with calcium alginate gel capsules. Process Biochem 36:601-606

Barmina I, Lickrastina A, Valdmanis R, Zake M, Arshanitsa A, Solodovnik V, Telysheva $G$ (2013) Effects of biomass composition variations on gasification and combustion characteristics. Eng Rural Dev Jelgava 05:23-24

Cabral JMS, Kennedy JF, Gupta MN (1993) Thermostability of Enzymes. Springer Verlag, Berlin, pp 163-179

Curti E, Bonacini G, Tribuzio G, Vittadini E (2013) Effect of the addition of bran fractions on bread properties. J Cereal Sci 57:325-332

Cyprian EO, Henrietta OO, Eguakun-Owie SO, Omonigho SE (2017) Fruit Wastes as Substrate for the Production of Amylase by Aspergillus niger. Trop J Nat Prod Res 1(4):182-185 
de Souza IA, Orsi DC, Gomes AJ, Lunardi CN (2019) Enzymatic hydrolysis of starch into sugars is influenced by microgel assembly. Biotechnol Reports (Amst) 22:e00342 https://doi.org/10.1016/j.btre.2019.e00342

Devi B, Unni BG, Wann SB, Samanta R (2012) Immobilization of partially purified alpha-amylase enzyme produced by a soil born Bacillus sp. Adv Appl Sci Res 3(5):2739-2744

Dey G, Singh B, Banerjee R (2003) Immobilization of a-Amylase Produced by Bacillus circulans GRS 313. Braz Arch Biol Technol 46(2):167-176

Djekrif-Dakhmouche S, Gheribi-Aoulmi Z, Meraihi Z, Bennamoun L (2006) Application of a statistical design to the optimization of culture medium for a-amylase production by Aspergillus niger ATCC 16404 grown on orange waste powder. J Food Eng 73:190-197

El-Banna TE, Abd-Aziz AA, Abou-Dobara MI, Reham II (2007) Production and Immobilization of a-Amylase from Bacillus subtilis. Pak J Biol Sci 10(12):2039-2047

El-Shahed KY, El-Diwany Al, Awad HM (2008) Enhanced production of streptomycin and hydrolytic enzymes by Streptomyces griseous strains using different types of organic solvents and detergent compounds. Indian J Biotechnol 7:341-348

Foukia, EM, Maysa EM, Elshibawy KH (2016) Optimization of alpha-amylase production, immobilization and characterization by isolated Bacillus lentus under solid-state fermentation. J Innov in Pharma and Biol Sci 3(4):26-32

Gerhartz W (1990) Enzymes in industry: production and applications. VCH, Weinheim; New York

Gupta R, Giras P, Mohapatra H, Gaswami YK, Chauhan B (2009) Microbial aamylase: a biotechnological perspective. Process Biochem 38(11):1599-1616

Gurung N, Ray S, Bose S, Rai V (2013) A broader view: microbial enzymes and their relevance industries, medicine, and beyond. Biomed Res Int 329121. https://doi.org/10.1155/2013/329121

Hamed ER, Awad HM, Ghazi EA, El-Gamal NG, Shehata HS (2015) Trichoderma asperellum isolated from salinity soil using rice straw waste as biocontrol agent for cowpea plant pathogens. J Appl Pharm Sci 5(1):091-098

Haq I, Ashraf H, Qadeer MA, lqbal J (2005) Pearl millet, a source of alpha amylase production by Bacillus licheniformis. Bioresour Technol 96:1201-1204

Hari PR, Chandy T, Sharma CP (1996) Chitosan/calcium alginate microcapsules for intestinal delivery of nitrofurantoin. J Microencapsul 13:319-329

Hemanchi HK, Sanjay NP (2019) Immobilization of a-amylase by entrapment method and its comparative study with free a-amylase. Int J for Res in Appl Sci \& Eng Technol 7(5):293

Hiri NM, loannou I, Ghoul M, Boudhrioua NM (2015) Proximate chemical composition of orange peel and variation of phenols and antioxidant activity during convective air drying. J of new sci, Agric and Biotechnol 9(1):881-890

Ichinose S, Tanaka M, Shintani T, Gomi K (2014) Improved a-amylase production by Aspergillus oryzae after a double deletion of genes involved in carbon catabolite repression. Appl Microbiol Biotechnol 98:335-343

Jain D, Katyal P (2018) Optimization of gluco-amylase production from Aspergillus spp. For its use in saccharification of liquefied corn starch. 3 Biotech 8(101):1-9

Kar S, Ray RC, Mohapatra UB (2008) Alpha-amylase production by Streptomyces erumpens MTCC 7317 in solid state fermentation using response surface methodology (RSM). Pol J Microbiol 57:289-296

Karnwal A, Nigam V (2013) Production of amylase by isolated microorganisms and its application. Int J Pharm Bio Sci 3(4):354-360

Karr-Lilienthal LK, Bauer LL, Utterback PL, Zinn KE, Frazier RL, Parsons CM, Fahey GC (2006) Chemical composition and nutritional quality of soybean meals prepared by Extruder /Expeiier processing for use in poultry diets. AgricFood Chem 54(21):8108-8114

Kathiresan K, Manivannan S (2006) a-amylase production by Penicillium fellutanum isolated from mangrove rhizosphere soil. African J Biotechnol 5(10): 829-832

Khan JA, Priya R (2011) A study on partial purification and characterization of extracellular amylases from Bacillus subtilis. Adv Appl Sci Res 2(3):509-519

Konsoula Z, Liakopoulou-Kyriakides M (2006) Thermostable a-amylase production by Bacillus subtilis entrapped in calcium alginate gel capsules. Enzym Microb Technol 39:690-696

Kumar D, Muthukumar M, Garg N (2012) Kinetics of fungal extracellular alphaamylase from Fusarium solani immobilized in calcium alginate beads. J Environ Biol 33:1021-1025

Mahajan R, Gupta VK, Sharma J (2010) Comparison and suitability of gel matrix for entrapping higher content of enzymes for commercial applications. Indian J Pharm Sci 72(2):223-228

Mandels M, Andreotti R, Roche R (1976) Measurement of saccharifying cellulase. Bioteh Bioeng Symp 6:17-37
Mojumdar A, Deka J (2019) Recycling agro-industrial waste to produce amylase and characterizing amylase-gold nanoparticle composite. Int J Recy Org Waste Agri 8:263-269

Nakase T, Komagata K (1971) DNA base composition of some species of yeasts and yeast-like fungi. J Gen Appl Microbiol 17:363-369

Nimkar MD, Deogade NG, Kawale M (2010) Production of alpha-amylase from Bacillus subtilis \& Aspergillus niger using different agro waste by solid state fermentation. Asia J Biotech Res 01:23-28

Oyeleke SB, Egwin EC, Auta SH (2010) Screening of Aspergillus flavus and Aspergillus fumigatus strains for extracellular protease enzyme production. J Microbiol Antimicrob 2:2141-2307

Pandey A, Webb C, Soccol CR, Larroche C (2005) Enzyme Technology. Asia tech Publishers, New Delhi

Pasin TM, Benassi VM, Moreira EA, Jorge JA, Polizeli ML (2014) Prospecting Filamentous Fungi for Amylase Production: Standardization of Aspergillus japonicus Culture Conditions. British Biotechnol J 4(4):482-498

Prakash O, Jaiswal N (2011) Immobilization of thermostable "a-amylase on agarose and agar matrices and its application in starch stain removal". World Appl Sci J 13(3):572-577

Ramachandran S, Patel A, Nampoothiri K, Francis F, Nagy V, Szakacs G, Pandey A (2004) Coconut oil cake -a potential raw material for the production of aamylase. Bioresour Technol 93:169-174

Ranjitha J, Bhuvaneshwari G, Terdal D, Kavya K (2018) Nutritional composition of fresh pomegranate peel powder. Int J Chem Studies 6(4):692-696

Rasul MG, Hiramatsu M, Okubo H (2007) Genetic relatedness (diversity) and cultivar identification by randomly amplified polymorphic DNA (RAPD) markers in teasle gourd (Momordica dioica Roxb.). Sci Hortic 111:271-279

Riaz A, Ansari B, Siddiqui A, Ahmed S, Naheed SUL, Qader SA (2015) Immobilization of a-amylase in operationally stable calcium-alginate beads: A cost effective technique for enzyme aided industrial processes. Int J Biotechnol Res 3(5):081-086

Riaz A, Qader SA, Anwar A, lqbal S, Bano S (2007) Effect of medium composition and time course on the production of alpha-amylase from Bacillus stearothermophilus. Pak J Biochem Mol Biol 40(2):51-54

Riaz A, UI Qader SA, Anwar A, labal S (2009) Immobilization of a thermostable aamylase on calcium alginate beads from Bacillus subtilis kibge-har. Aust J Basic Appl Sci 3(3):2883-2887

Rizk MA, El-Kholany EA, Abo-Mosalum EMR (2019) production of a-amylase by Aspergillus niger isolated from mango kernel. Middle East J Appl Sci 9(1):134-141

Saleh AM, Esam I, Azhar I, Ba-Akdah MM, Nisreen RT, Kumosani TA (2011) Production, purification and characterization of a-amylase from Trichoderma harzianum grown on mandarin peel. Afr J Microbiol Res 5(9):1018-1028

Sidkey NM, Maha A, Reham B, Reham S, Ghadeer B (2011) Purification and characterization of a-amylase from a newly isolated Aspergillus flavus F2Mbb. Int Res J Microbiol 2:96-103

Singh S, Singh S, Bali V, Sharma L, Mangla J (2014) Production of fungal amylases using cheap, readily available agri residues, for potential application in textile industry. Biomed Res Int 2014(215748):9 https://doi.org/10.1155/2014/215748

Talekar S, Chavare S (2012) Optimization of immobilization of a-amylase in alginate gel and its comparative biochemical studies with free a-amylase. Recent Res Sci Technol 4(2):01-05

Talekar S, Ghodake V, Kate A, Savant N, Kumar C, Gadagkar S (2010) Preparation and characterization of crosslinked enzyme aggregates of Saccharomyces cerevisiae invertase. Aust J Basic Appl Sci 4:4760-4765

Tamura K, Stecher G, Peterson D, Filipski A, Kumar S (2013) MEGA6: Molecular Evolutionary Genetics Analysis version 6.0. Mol Biol Evol 30:2725-2729

Varalakshmi KN, Kumudini BS, Nandini BN, Solomon J, Suhas R, Mahesh B, Kavitha AP (2009) Production and characterization of alpha-amylase from Aspergillus niger JGl 24 isolated in Bangalore. Pol J Microbiol 58:29-36

Vidyalakshmi R, Paranthaman R, Indhumathi J (2009) Amylase production on submerged fermentation by Bacillus spp. World J Chem 4(1): 89-91

White TJ, Bruns TD, Lee SB (1990) Amplification and direct sequencing of fungal ribosomal RNA genes for phylogenetics. In: Innis NA, Gelfand J, Sninsky J (eds) PCR protocols: a guide to methods and applications. Academic Press, San Diego

Zusfahair I, Ningsih DR, Kartika D, Fatoni A, Permatawati I (2017) Immobilization and characterization of Bacillus thuringiensis HCB6 amylase in calcium alginate matrix. Molekul. 12(1):70-77

\section{Publisher's Note}

Springer Nature remains neutral with regard to jurisdictional claims in published maps and institutional affiliations. 